\title{
Unemployment and Drug Trafficking Among Suspects in Custody of the National Drug Law Enforcement Agency, Cross River State Command, Nigeria
}

\author{
Adeniyi, Emmanuel Kayode, \\ Eneji, Rosemary I., \\ Okpa, John Thompson, \\ National Drug Law Enforcement Agency, \\ University of Calabar, Calabar, Nigeria
}

Doi:10.19044/esj.2019.v15n19p191 URL:http://dx.doi.org/10.19044/esj.2019.v15n19p191

\begin{abstract}
The objective of this study is to determine the relationship between unemployment and drug trafficking in Nigeria with particular reference to suspects in custody of the National Drug Law Enforcement Agency (NDLEA), Cross River State Command. Purposive sampling technique was adopted to select one hundred and twenty-seven (127) respondents (suspects) from the study area, to which standard questionnaires were administered. The generated data were statistically analysed using Pearson Product Moment Correlation analysis to estimate the relationship under study. The findings of the study revealed that there were significant direct relationships between unemployment and drug trafficking and between un-employability and illicit drug trade. Lack of entrepreneurial skills had a positive link with drug trafficking. As a solution, the study recommended that government at all levels should create or encourage the private sector to offer, more jobs for the teeming unemployed youths, promote small and medium scale enterprises for the unemployed through empowerment programmes and provide unemployment benefits for the jobless.
\end{abstract}

Keywords: Unemployment, drug trafficking, law enforcement, entrepreneurial skills, Nigeria

\section{Introduction}

Unemployment and drug trafficking constitute a global problem affecting developed and developing countries alike. They are not only a serious economic issue, but have social implications for almost all countries 
and people, either directly or indirectly. The unemployment situation in Nigeria has assumed a multi-dimensional phenomenon, cutting across all age groups, educational strata and geography, to become a serious social problem with potentially dangerous impact on all sectors of the society (Agba and Ushie, 2014). The effect of unemployment on job seekers goes beyond the financial loss as it also affects their sense of identity and ability to structure or organise their time meaningfully. Thus, the unemployed reacts to absence of work in a series of ways; often they are shocked by their unemployed situation, which creates a disorientation in them as they suffer from anxiety and distress.

In Nigeria, the unemployed includes school leavers, graduates, and retrenched workers from both multi-national and small-scale industries, plus others who are virtually unskilled and have no job (Idoko, 2013). The Nigerian ailing economy has contributed significantly to the high unemployment among citizens, resulting to youth engaging in drug trafficking and other crimes as a means to earn a living. The problem of unemployment in Nigeria can be traced to disequilibrium between labour market requirements and lack of prerequisite skills by young people and poor entrepreneurship as well as inadequate vibrant manufacturing industries (Robert, 1991; Diejohan and Orimolade, 1991; Debalen and Adekola 2000).

Illicit drug trade has led to the creation of local markets for the consumption of illicit drugs such as Cannabis, Cocaine, Heroin, Amphetamines, Methamphetamines, and other mind-altering psychotropic substances (Adeniyi, 2017). The abuse of these drugs has resulted to damaging health problems, broken homes, domestic violence, low productivity, loss of job, road traffic accidents and delinquent acts like stealing, pilfering, truancy, assault and rape. The after-effect of drug trafficking has invariably led to drug abuse and other associated crimes such as armed robbery, burglary, arson, assassination, kidnapping, militancy, terrorism, insurgency and political thuggery (Okpa \& Ekong, 2017; Ukwayi \& Okpa, 2017; Okpa \& Ukwayi, 2017). The problem of illicit drug trade is a social evil that is assuming different and dangerous dimension, with its attendant consequences on the safety of lives and property across Nigeria (Iwarimie-Jaja, 2012; Okpa \& Ukwayi, 2017). Drug trafficking has led to the arrest, prosecution, conviction and execution of young Nigerians in foreign countries over drug related offences. This development has adversely affected the productive work force of the country. Also worrisome is a situation where persons arrested, persecuted and convicted for drug-related offenses, after serving jail terms or while on bail often return to illicit drug commerce. This action tends to portray that unemployment is a propelling force for them to engage in drug trafficking.

Drug trafficking has been widely studied by various researchers; however, it is still attracting the interest and concern of more researchers (Adeniyi, 2004; Adeniyi, 2016; Godwin, 2007; Maqbool, 2014; Okpa \& 
Ukwayi, 2017). While some research information is available on the relationship between unemployment and crime generally, there is a near absence of empirical studies on the relationship between unemployment and drug trafficking. The goal of this research is to bridge the knowledge gap and make available empirical facts on the subject under investigation, based on the following research questions: 1. To what extent does lack of employability skills explain drug trafficking? 2. What is the relationship between lack of entrepreneurial skill and drug trafficking? The specific objective was to examine the relationship between unemployment and drug trafficking among drug suspects in NDLEA custody, Cross River State Command, Nigeria. Our hypotheses were that 1 . There is no significant relationship between lack of employability skills and drug trafficking and 2. There is no significant association between lack of entrepreneurial skills and drug trafficking in Cross River State.

\section{$1.1 \quad$ Study area}

The study area was the National Drug Law Enforcement Agency, Cross River State Command. The command headquarters is located at No. 3 Harbour Road, along Calabar Seaport Calabar, in Calabar Municipality Council of Cross River State. The State Command has three Area commands, namely: Calabar seaport, Ikom and Ogoja Area Commands. There are other operational beats where interdiction activities are carried out and these include Odukpani motorized patrol, Ikang water territory post, Mfum border, Margret Ekpo International Airport, Calabar Jetty, Yahe motorized patrol and Akpabuyo motorized patrol beat. The act establishing the NDLEA also allows it to have presence in every customs beats, posts and areas. The agency is also empowered to bear arms of the law just as members of the Nigeria police. The administrative and operational activities of the NDLEA, Cross River State command cover the entire parts of Cross River State, Nigeria. The command executes both demand reduction and supply control strategies to curb the drug problem in the state through the four principal units of:

(i) General Operation and Investigation.

(ii) Drug Demand Reduction

(iii) Prosecution and Legal Services

(iv) General Administration and Logistics

\section{Theoretical background}

\subsection{Strain theory}

In an attempt to provide explanation for increase in crime occurrence in the United States of America towards the middle of the twentieth century, Robert Merton posits that the social system instils in its members a desire for certain goals and prescribes socially approved means for realizing such goals 
(Ugwuoke, 2010). After critical appraisal of American social and cultural pattern, Merton formulated five methods through which American citizens reacted to the country's cultural goals. Merton had reasoned that if a person's cultural goals are thwarted through the application of legitimate means, he may adopt illegitimate methods in the alternative. Merton outlined the following means of adaptation:

(i) Conformity: At this level of adaptation, the individual accepts the culturally defined goals and adhere to institutionalized means to achieving them irrespective of his or her success or failure.

(ii) Innovation: In this mode of adaptation, individuals hold fast to the culturally highlighted goals of success but since the institutionalized means to achieve the goals are not accessible, they pursue their goals in innovative or illegal ways.

(iii) Ritualists: This consists of people who abide by rules (means) but lack the commitments to the goals. In other words, they reject the goals but accept the means.

(iv) Retreatists: The retreatists initially accepted both cultural goals and means of attaining them. But because of their inability to achieve these goals, they withdraw back from the struggle by rejecting both the goals and the approved means.

(v) Rebellion: This category of people feels that certain goals in the society are difficult to attain if not impossible and that the approved means to attain them are not workable. Therefore, they reject both goals and means of the society and substitute them with new sets of values and norms for the discarded ones. Accordingly, such individuals withdraw their allegiance from existing loyalties and arrangement and transfer them to new groups with new ideologies.

This theory has implications to the study whose interest is on unemployment and drug trafficking in Cross River State, Nigeria. In Nigeria, educational attainment and wealth are greatly valued. Although such goal is supposed to be pursued by using institutionalized means as occupational skills and ability, due to the increasing unemployment rate a substantial number of Nigerians cannot achieve the prescribed goals through institutionalized means. Hence some individuals (drug traffickers) who have higher value and affinity to material possession and prestige would reject society's expected means of achieving these materials to initiate or design their own means of getting these prescribed goals, thereby get involved in those social vices such as drug trafficking among others in order to enrich themselves. They in the process break societal norms. 
The study population consisted of male and female drug suspects arrested for alleged engagement in the distribution, transportation, sale, dealing, peddling, possession and cultivation of narcotic drugs and psychotropic substances in Cross River State, Nigeria. In view of the small number of the population, the total population of the study was used as the sample for this study. Thus, all the one hundred and twenty-seven (127) suspects in NDLEA custody in Cross River State Command constituted the sample for the study.

Purposive sampling technique was adopted because the respondents (suspects) had been identified in their confinement in NDLEA custody. This made it convenient for the researchers to interview drug suspects within pretrial detention facilities for first-hand (primary) information. In this study, standard questionnaires were used as the main tool for primary data. The questionnaire was entitled "Unemployment and drug trafficking" (QUDT). Each item in the questionnaire required the respondents to indicate the strength of agreement under Strongly agree (SA), Agree (A), Disagree (D) and Strongly Disagree (SD). The questionnaire was subjected to face and content validity by experts in Educational Tests and Measurements. Pearson Product Moment Correlation was adopted in the analysis of the coded responses. Secondary sources of data were from review of the works of other scholars, especially information on the major variables for the study. Gazetted materials, station diaries, registers, journals and records formed a significant source of the secondary data.

\section{$4 \quad$ Results}

Table 1 shows the respondent's demographic information. Majority of the suspects $(79.5 \%)$ were males while only 20.5 were females. This suggests that males are more involved in drug trafficking because they are physically aggressive, more physically active, more logical and often have good special skills. Also, the frequent pressure on men to provide for their families as "breadwinners", in the absence of a job has increased their number in drug trafficking. About $20.5 \%$ of the suspects were below 25 years, $30.7 \%$ were between 26 and 35 years, $26.0 \%$ were between 36 and 45 years, $15.7 \%$ were aged $46-55$ years while only $7.1 \%$ were above 56 years. All the age groups are represented since age is not a barrier to committing crime. However, respondents within the active working age group ( $26-55$ years) constituted the majority and dominate the illicit drug trafficking. This is because Nigeria's population largely consists of young people and lack employment opportunities in the country might tempt them to commit drug-induced crime to get rich quick. 
About $46 \%$ of the suspects were single, $40.2 \%$ were married and 13.4 $\%$ were divorced or separated. This showed that both single and married suspects were actively involved in illicit drug commerce. In terms of occupation, , majority of the suspects claimed to be self-employed $(33.1 \%)$, $28.3 \%$ were unemployed, $19.7 \%$ were traders, $11.0 \%$ were farmers, $7.9 \%$ engaged in other trades such as fishing, private business, artisans, students and so on. The self-employed whose income is too low to guarantee a better standard of living are more involved in illicit drug enterprise. Most of them admitted that their trading business did not earn them enough money to meet their responsibilities. This is followed by the unemployed who are jobless or applicants that are easily lured into drug trafficking. The involvement of respondents of other occupational categories in illicit drug commerce can be ascribed to low-income brought about by low educational qualifications, general meltdown in the economy and underemployment, which serve as driving force for illicit drug trade.

Based on religious affiliation, majority $(61.4 \%)$ of suspects practiced Christianity; the group with the least representation was Islam faithful with only 14.2\%; African Tradition Religion faithful constituted $24.4 \%$. The dominance of Christians was because the study was carried out in the state where Christianity is the main religion.

In terms of educational qualification, $15.0 \%$ of the suspects had no formal education, $22.8 \%$ completed primary education, $30.7 \%$ completed secondary education, $18.9 \%$ completed NCE/OND $6.3 \%$ had HND/B.Sc.. This distribution shows that majority of the drug suspects ( 68.5 per cent) have either no formal education, or low (primary and secondary) educational attainment. This category of people may be desperate to get rich quick and this might be responsible for their involvement in illicit drug trade. Those with higher educational qualifications have self-esteem, self-value and worth with the hope that their educational attainment will guarantee them better jobs. This is enough to discourage them from taking the risk of trafficking in dangerous drugs and thereby avoid the embarrassment of being arrested and convicted for illicit drug trade.

Table 1: Personal/demographic information of respondents (drug suspects)

\begin{tabular}{llll}
\hline Variables & & $\mathrm{N}$ & Percentage \\
\hline Gender & Male & 101 & 79.5 \\
& Female & 26 & 20.5 \\
Tge & Total & $\mathbf{1 2 7}$ & $\mathbf{1 0 0}$ \\
& Below-25 & 26 & 20.5 \\
& $26-35$ & 39 & 30.7 \\
& $36-45$ & 33 & 26.0 \\
& $46-55$ & 20 & 15.7 \\
Marital status & 56-above & 19 & 7.1 \\
& Total & $\mathbf{1 2 7}$ & $\mathbf{1 0 0}$ \\
\hline
\end{tabular}




\begin{tabular}{|c|c|c|c|}
\hline & Married & 51 & 40.2 \\
\hline & Divorced/separated & 17 & 13.4 \\
\hline & Total & 127 & 100 \\
\hline \multirow[t]{7}{*}{ Occupation } & Civil servant & 0 & 0 \\
\hline & Trading & 25 & 19.7 \\
\hline & Farming & 14 & 11.0 \\
\hline & Self employed & 42 & 33.1 \\
\hline & Unemployed & 36 & 28.3 \\
\hline & others & 10 & 7.9 \\
\hline & Total & 127 & 100 \\
\hline \multirow{7}{*}{$\begin{array}{l}\text { Educational } \\
\text { qualification }\end{array}$} & No formal education & 19 & 15.6 \\
\hline & Primary & 29 & 22.8 \\
\hline & Secondary & 39 & 30.7 \\
\hline & NCE/OND & 24 & 18.9 \\
\hline & HND/B.Sc. & 8 & 6.3 \\
\hline & Others & 8 & 6.3 \\
\hline & Total & 127 & 100 \\
\hline \multirow[t]{7}{*}{ Drug offence } & Cannabis & 57 & 44.9 \\
\hline & Cocaine & 22 & 17.3 \\
\hline & Combine & 17 & 13.4 \\
\hline & Depressant & 11 & 8.7 \\
\hline & Heroine & 14 & 11.0 \\
\hline & Others & 6 & 4.7 \\
\hline & Total & 127 & 100 \\
\hline \multirow[t]{6}{*}{ Predisposing factor } & Unemployment & 63 & 49.6 \\
\hline & Quick money & 29 & 22.8 \\
\hline & Peer group & 19 & 15.0 \\
\hline & Ignorance & 13 & 10.2 \\
\hline & Others & 3 & 2.4 \\
\hline & Total & 127 & 100 \\
\hline \multirow[t]{4}{*}{ Concealment } & Sack & 30 & 23.6 \\
\hline & Pocket & 27 & 21.3 \\
\hline & Others & 70 & 55.1 \\
\hline & Total & 127 & 100 \\
\hline
\end{tabular}

Source: Field information (2018)

The most frequently trafficked drug in the command was cannabis, with a representation of $44.9 \%$. Cocaine is second with $17.3 \%$, followed by $13.4 \%$ for mixed drugs, $11.0 \%$ for heroine, $8.7 \%$ for depressant and $4.7 \%$ For other drugs. It is a fact that cannabis is cultivated illegally in different parts of the country and this makes the drug to be the most trafficked in the state and country. This is aided by the favourable soil and climatic conditions for cultivation and growth.

As shown in Table 1 for predisposing factors, $49.6 \%$ of the suspects engaged in drug trafficking as a result of unemployment, followed by $22.8 \%$ for the desire to get-rich-quick, $15.0 \%$ for group influence, $10.2 \%$ for ignorance and $2.4 \%$ for other factors. For the mode of drug concealment, 55.1 $\%$ of suspects concealed illicit drugs through means not highlighted in the 
questionnaire such as jerry cans, drums, plastic containers, bags, roofs, tins and nylons; $23.6 \%$ concealed them in sacks while only $21.3 \%$ concealed them in their pockets.

A summary of the analysis of data testing our hypothesis 1 that there was no significant relationship between lack of employability skills and drug trafficking is shown in Table 2. There was a highly significant positive correlation between lack of employability skills and drug trafficking $(r=0.583$; $\mathrm{p}<.05)$. The null hypothesis of no significant relationship was therefore rejected.

Table 2: Pearson Product Moment Correlation between lack of employability skills and drug trafficking

\begin{tabular}{|c|c|c|c|c|c|}
\hline Variable N & $\mathrm{X}$ & $\mathrm{SD}$ & $\mathrm{r}$ & Sig. & (2-tailed) \\
\hline Lack of employability skills & 127 & 14.71 & 2.69 & \multirow[b]{2}{*}{$0.583 * *$} & \multirow[b]{2}{*}{.000} \\
\hline Drug trafficking & 127 & 15.66 & 2.71 & & \\
\hline
\end{tabular}

Table 3 shows the summary of the analysis of hypothesis 2 that there was no positive association between lack of entrepreneurial skills and drug trafficking. Again, there was a highly significant positive association between lack of entrepreneurial skills and drug trafficking. $(r=0.138 ; \mathrm{p}<.05)$. The null hypothesis was thus rejected.

Table 3: Pearson Product Moment Correlation Analysis of the relationship between lack of entrepreneurial skills and drug trafficking

\begin{tabular}{llllll}
\hline Variable N & $\mathrm{X}$ & SD & r & Sig. & (2-tailed) \\
\hline Lack of entrepreneurial skills & 127 & 11.27 & 1.91 & & \\
& & & & $0.366^{* *}$ & .000 \\
Drug trafficking & 127 & 15.66 & 2.71 \\
\hline \multicolumn{4}{c}{ *Significant at .05, r-calculated $=0.366$, r-critical $=0.138 \mathrm{df}=125$} \\
\end{tabular}

\section{Discussion}

\subsection{Employability skills and drug trafficking}

A statistical analysis of hypothesis one revealed a significant relationship between lack of employability skills and drug trafficking in Cross River State, Nigeria. The lack of employability skills explains why job seekers traffic illicit drugs. It reveals further that workers who lost their jobs as a result of lack of employability skills engage in drug trafficking for survival. This corroborates earlier reports (Sodipo, 2010; Olatunji and Abioye, 2011; Oladele et al., 2011; Agbeze, 2012) that employability skills were usually lacking among job seekers, especially graduates just out of school and even those without formal education. During high unemployment, employers have more choice of applicants and will often favour those with well-rounded employability skills. However, those without jobs often engage in unconventional means of survival like trafficking in illicit drugs. 
Olatunji and Abioye (2011) reported a mis-match between the teaching in tertiary institutions and the needs of the labour market, and therefore emphasized that students should be given life-skills needed to navigate murky waters of life. Thus, employers would want curriculum designed in such a way that promotes conceptual and creative thinking, selfawareness, sense of career direction and emotional intelligence. The absence of these qualities among job seekers has compounded the problem of unemployment in the country. Similarly, Sodipo (2010) reported that Lack of employability skills due to inappropriate school curricula was contributing factor to the increasing unemployment rate, which resulted to rising cases of drug trafficking in the Nigeria.

\subsection{Entrepreneurial skills and drug trafficking}

Findings of this study indicate a positive association between lack of entrepreneurial skills and drug trafficking. The inability of job seekers to acquire entrepreneurial skills is responsible for their involvement in trafficking drugs. The unemployed who lack entrepreneurial skill engages in drug trafficking to meet his needs. Also, the inability of the unemployed to raise money to set up businesses is responsible for their trading in illicit drug for quick gain as reported previously ( Agba and Ushie, 2014; Ejere and Tende, 2012; Egwu, 2014; Saridakis and Spengler, 2009).

Agba and Ushie (2014) attributed the high unemployment to low degree of entrepreneurial activities; that is, where the propensity to set up enterprises is low, the rate of unemployment would be very high. The unemployed tend to remain so because they have lower endowments of human capital and entrepreneurial talents required to start and sustain new firms to keep them going. A low rate of entrepreneurship culture and skills in any society may be a consequence of the low economic growth, which also reflects higher levels of unemployment and increasing involvement in drug trafficking. Although greed may play a role in this unacceptable social behaviour, the lack of entrepreneurial skills remains a major factor in emergence and escalation of drug-related problems.

Ejere and Tende (2012) found that lack of entrepreneurial skills was responsible to a large extent, for the level of social complications of armed robbery, political thuggery, drug peddling, prostitution, money laundering, currency counterfeiting, e-mail scam, and other such related crimes. They stated that when individuals are unable to satisfy their needs, most often, frustration occurs. These frustrations breed fraudulent practices that culminate into social problems. Employment generation through entrepreneurship has the potency to reduce the level of frustration and consequently, crime rate. Entrepreneurship through job and wealth creation raises the standard of living of people. Owing to higher income earning and availability of disposable 
income, people can afford the basic necessities of life such as housing, clothing and food, education, good health care and so on, which will keep them away from criminal behaviours such as drug trafficking (Egwu, 2014).

\section{Conclusion and recommendations}

The study was designed to investigate the relationship between unemployment and drug trafficking among suspects in NDLEA custody, Cross River State Command, Nigeria. We examined how lack of employability and entrepreneurial skills relate to drug trafficking. We concluded that:

(i) There was a highly significant direct relationship between lack of employability skills and drug trafficking. This implies that in the face of increasing unemployment rate, job seekers who lack employability skills easily go into trafficking in illicit drugs for survival.

(ii) There was a significant association between lack of entrepreneurial skills and drug trafficking, suggesting that job seekers who lack entrepreneurial skills are more prone to trade in illicit drugs as a means of sustaining themselves from the pains of hardship. They are often recruited as agents, couriers, traffickers and peddlers by drug barons.

We suggest that there is need to equip undergraduates and other school leavers with necessary skills that will give them adequate potentials to be gainfully employed in any organisation. Therefore, establishment of skills acquisition centres throughout the state becomes very necessary and vital. With employability skills, people would be able to seek for jobs, keep the job and even change job when the need arises. There is also need to introduce entrepreneurial courses in our tertiary institutions of learning. This will equip undergraduates with entrepreneurial skills that will make them innovative and resourceful in setting up small-scale businesses for self-employment after leaving school. The provision of job opportunities and wealth creation by government would be a step in the right direction. Government should empower and strengthen institutions already established to provide job opportunities for teeming army of unemployed youths in Nigeria. Such institutions like National Directorate of Employment (NDE), Small and Medium Scale Enterprises Development Agency of Nigeria (SMEDAN), the National Poverty Eradication Programme (NAPEP), the National Economic Emancipation and Development Strategy (NEEDS), among others should be properly funded and empowered to meet their objectives of combating unemployment and poverty and wealth generation.

\section{References:}

1. Adeniyi, K. E. (2004). Drug laws in Nigeria. NDLEA perspective. Paper presented at NYSC orientation camp. Iyana-Ipaja, Lagos. 
2. Adeniyi, K. E. (2016). Unemployment and drug trafficking among drug suspects in NDLEA custody, Cross River State Command, Nigeria. Unpublished M.Sc. Thesis submitted to the Department of Sociology, University of Calabar, Calabar.

3. Agba, A. O. \& Ushie, E. M. (2014). Essential readings in social policy and programme. Calabar: University of Calabar Press

4. Chigunta, F. (2001). Youth livelihoods and enterprise activities in Zambia. Report to IDRC, Canada.

5. Dabalem, A., Oni, B. \& Adekola, A. (2000). Labour market prospects for university graduates in Nigeria. Washington, D.C.: World Bank.

6. Diejomaoh, U. \& Orimolade, W. (1991). Unemployment in Nigeria: Economic analysis of scope, tends and policy issues. Nigerian Journal of Economic and Social Sciences, 13(2), 127-132.

7. Egwu, I. L. (2014). Entrepreneurship development in Nigeria: A review. IOSR Journal of Business and Management, 16 (5) 1-7.

8. Ejere, A. K. \& Terde, U. C. (2013). Youth joblessness: Employability skills as an intervention mechanism. Afr. J. Bus. Manage. 3(4): 831835.

9. Godwin, A. (2007). Drug trafficking: An alarming human security threat. Accra, WARN policy brief

10. Idoko, I. F. (2013). The paradox of youths unemployment in an oil producing country: The lesson from the Nigerian experience. International Journal of Business and Management Invention, 4(2), 2319-8028.

11. Iwarimie-Jaja D. (2012). Criminology: The study of crime. 4th edition. Owerri; Spring-field publisher ltd.

12. Maqbool, T. (2014). Drug trafficking: A non-traditional security threat to national security of Pakistan. Islamabad institute for strategic studies research and analysis. (ISSRA)

13. Ndiyo, N. A. (2005). Fundamentals of research in behavioural sciences and humanities. Calabar: Wusen Press.

14. Okpa, J. T. \& Ukwayi, J. K. (2017). Drug suspects perception of factors responsible for illicit drug trade in Cross River State, Nigeria. IOSR Journal of Humanities and Social Science (IOSR-JHSS), 22(5), 80-87

15. Okpa, J. T., \& Ekong, I. (2017). Global and National Terrorism: Implications for Sustainable Development in Nigeria. IOSR Journal of humanities and social science (IOSR-JHSS) 22, (2), 49-56

16. Oladele, P. O., Akeke, I., Oladunjoye, O. (2011). Entrepreneurship development: A panacea for unemployment reduction in Nigeria. Journal of Emerging Trends in Economics and Management Sciences (JETEMS), 2 (4), 251-256. 
17. Olatunji, S. \& Abioye, O. (2011). Lecturers, students, others killed in Kaduna. The Punch, Wednesday, 20 April.

18. Oseni, A. I., Ali-Momoh, B. \& Momodu, Z. A. (2012). Repositioning Nigerian youths for economic empowerment through entrepreneurship education, Research Journal in Organisational Psychology and Educational Studies, 1(1), 43 - 47.

19. Robert, B. (1991). Economic growth in a cross section of countries. Quarterly Journal of Economic, 106(2), 407-414.

20. Saridakis, G., \& Spengler, H. (2009). Crime, deterrence and unemployment in Greece: A panel data approach. Di Berlin. German: Institute for Economic Research.

21. Sodipo, O. O. \& Attoh, E. H. (2009). Employability of tertiary education graduates in Nigeria: Closing the skills-gap. Global Journal of Human Resource Management, 2 (3), 28-36

22. Sodipo, Olufunlayo (2010). Tertiary education graduates' level of competency in Ogun State civil service. Survey report as part of synopsis on a colloquium on organized private sector/public service demand for Nigerian universities, College of Education and Polytechnic Graduates Employability Organized by Bureau of Tertiary Institutions Abeokuta, Ogun State, Between 12th And 13th October 2010.

23. Ugwuoke, C. U. (2010). Criminology: Explaining crime in the Nigerian context. Nssuka: Great Ap Express Publishers Ltd.

24. Ukwayi, J. K. \& Okpa, J. T. (2017). The effect of electoral and economic crimes on sustainable development in cross river state, Nigeria. International Journal of Social Science Research 5 (2), 32-42. 